\title{
sciendo
}

DOI 10.2478/sbe-2020-0050

SBE no. 15(3) 2020

\section{ANTICIPATING A REVERSE MORTGAGE ADOPTION IN CROATIA}

\author{
KUNDID NOVOKMET ANA \\ Faculty of Economics, Business and Tourism, University of Split, Croatia \\ MATKOVIĆ MARTINA \\ International Medical Corps, Split, Croatia
}

\begin{abstract}
:
Reverse mortgage is an alternative source of financing of elderly population that usually has some homeownership, but insufficient income and savings to support desired or indispensable level of consumption. It is a financial innovation mostly provided by banks and finance companies to seniors, which enables a home equity conversion to liquidity without selling or leaving a property. In circumstances of ageing society, modest pension income, increasing long-care expenditures, limited access to loan market and high risk of poverty, a reverse mortgage product has a solid ground for implementation and adoption. Croatia is an ageing country with negative demographic trends, which accelerated in the last few years. Retired population which is "home rich and cash poor" is particularly vulnerable and at strike to sustain a decent life. Therefore, we raised a question concerning the justification of the reverse mortgage introduction in Croatia. After giving an insight into some contextual factors, an estimation of the potential demand for reverse mortgage service in Croatia was made by carrying out an exploratory - pilot study with around 120 questionnaire respondents. We found out that there is a poor knowledge about the reverse mortgage among Croatian financial consumers (i.e. only $24 \%$ of respondents are familiar with the reverse mortgage term), as well as the lack of demand for this home equity extraction instrument. Namely, almost $67 \%$ of respondents would not accept a reverse mortgage instrument regardless of the circumstances, primarily due to socio-cultural reasons.
\end{abstract}

Key words: demand for financial services, reverse mortgage, banks, questionnaire, Croatia

\section{Introduction}

Reverse mortgages (RM) or home equity conversion mortgages "enable property to be converted into cash flows guaranteed by the subsequent sale of an asset, while still guaranteeing borrowers the right to use the property concerned" (Cosma et al., 2019, p. 1275). In other words, "it is a form of financial agreement 
between a reverse mortgage lender and a borrower that allows older people to convert the real value of their property into a loan in the form of cash advances that do not require any future payments" (Husáková et al., 2018, p. 623). Namely, the borrower, who is also a homeowner, is not required to pay principal and interests, usually until he or she sells the property, moves away from it, or lastly passes away. To sum up, as the time passes by, homeowners collect income from a bank instead of having some repayment obligation. In return, bank's ownership over the property is increasing, until the home value is fully exempted and ownership finally transferred to the reverse mortgage provider. Apparently, RM loans are targeted for elderly households with an appropriate and significant housing wealth as a source of liquidity buffer in case of inadequate pension income, insufficient retirement savings or severe credit constraints. According to assessment for 2013, senior citizens' home equity amounts about 5 trillion EUR in the US and over 8 trillion EUR in large EU countries (Haurin and Moulton, 2017, p. 245).

Despite countless demographic and economic problems, most of the countries globally are coping with, likewise population ageing, unsustainability of pension systems, and the lack of public resources for elders, just to mention a few, what should altogether contribute to a widespread usage of the private financial instruments such as RMs, they remain a marginal source of financing. For instance, "only about $2 \%$ of the eligible elderly homeowners are reporting borrowing against their housing wealth" on the most developed RM market in the world - those of the US in the year 2011 (Nakajima and Telyukova, 2014; Chatterjee, 2016, p. 1; Moulton et al., 2017). In the EU, RMs account "less than $1 \%$ of the total mortgage market", with Ireland, Spain and the UK at the forefront, making the three-quarters of the total RM business (SimónMoreno, 2019, pp. 1007-1008). Many scholars strive to explain an obvious gap between the potential and real demand for the RM loans by analyzing the reasons behind their acceptance or refusal. Oftentimes, they conclude that the demand for the $\mathrm{RM}$ product is restricted because of the bequest motive, high contract costs, product complexity and insufficient financial knowledge. On the other hand, empirical investigations are inconsistent about the determinants of interest in the RM product, especially when financial consumers residing in different countries are taken into consideration. Thus, exploring the attitudes of financial consumers towards the RM loans for countries with a presupposed emerging potential of the RM market is reasonable and worthwhile. The post-socialist countries of Central and Eastern Europe (CEE) have been minimally included in the academic discourse on the subject (Sendi et al., 2019, p. 578). We contribute to this topic with Croatian citizens in the spotlight.

Croatia is demographically deteriorating. The population is aging because of an increased life expectancy rate like elsewhere, but also due to an exodus of younger citizens to the more developed EU countries in the last few years, when severe unemployment and other economic problems took place. Thus, the demographic issues are derived from the bad general economic conditions. In addition, an average pension income is quite modest and the risk of poverty is higher among the retired population. The population projections are also discouraging (EUROPOP2018, 
Eurostat). In 2018, the median age of Croatia resident was 43,7 years, while it is assumed to be 51,3 years in 2050 , when the EU-28 average is expected to be 46,9 years. Furthermore, the proportion of Croatian citizens that were $65+$ was $20,1 \%$ in 2018. When compared to the expected EU-28 average for $2050(28,5 \%)$, Croatia will have higher proportion of those aged 65 years and more $(31,6 \%)$. The average life expectancy will reach 81,1 years for males and 86 years for females in 2050, what represents an increase of 6 years for males and 4,9 years for females since 2018. Furthermore, people in Croatia are prone towards owning homes. The data for Croatia in 2017 confirm that more than $90 \%$ of people aged 65 years or more are living alone in their own homes that are free from any outstanding mortgages or housing loans, but they express a great concern over not having sufficient income (Ageing Europe looking at the lives of older people in the EU, 2019, pp. 37 and 105). In addition, the real-estate prices have rocketed in the most of Croatia in the last few years, mainly due to a high touristic attractiveness of the country. If we exclude the (nonexistent) legal framework, a quite number of objective conditions, which are important for the RM market development, are met in the case of Croatia. Nevertheless, the potential demand for this product is still unknown and on-hold regarding any estimations. To our best knowledge, this is the first article, which reveals results of a questionnaire research about the RM product acceptance in Croatia. Thus, it provides useful insight into a potential interest of Croatian citizens in the RM loans, what might be interesting to bank managers and public policymakers. To be more precise, the study addresses the following research questions:

RQ1. Which socio-economic characteristics of individuals explain their familiarity with the RM?

RQ2. What are the main reasons behind the RM acceptance/rejection?

RQ3. Do socio-demographic characteristics affect the propensity towards RM acceptance?

RQ4. What is the general attitude of respondents towards the Croatian banking sector and frequency of using the bank loans?

The answers are based on the data set, which is collected throughout a questionnaire survey and analyzed by using the univariate statistics. In the nutshell, there is a lack of financial consumers' interest for introducing the RM loans in Croatia for the time being. Obtained results are in line with those for other CEE countries, likewise Slovenia (Sendi et al., 2019), Slovak Republic (Husáková et al., 2018) or Poland (Zbrojewski, 2013).

The rest of the paper is organized as follows: the second section elaborates the basic features of the RM loans, while the third section reviews empirical literature on the determinants of RM market development, with a priority given to surveys which center around financial consumers' attitudes concerning the RM product. The methodological aspects and the research results of the empirical analysis of Croatian citizens' awareness and affinity towards the RMs are given and discussed in the fourth section. The fifth section summarizes the key findings. 


\section{A general insight into the RM product}

The literature about the RM financial instrument has flourished in the last decade, and many studies worldwide have attempted to disclose arguments for the RM market development in certain country as well as expected micro and macroeconomic benefits of RM acceptance. Despite that, a full potential of the RM financing remains unexploited. In order to find out why is that so, a brief review of the aforementioned financial innovation characteristics is required.

RM differs from the ordinary mortgage in its features, the requirements and process of approval as well as targeted clients (Table 1). Namely, RM is a loan without regular repayment obligation during a lifetime, which is directed towards elderly population with some homeownership, but insufficient income to cover their regular, occasional or one-off expenses. In short, it means "to liquidate home equity for consumption", particularly in case of unexpected events, rather than for supplementing current consumption (Moulton et al., 2017, p. 76). It was designed for the retired population, and thus the minimally requested age for the RM application varies among the countries which legally permitted the RM introduction, from the lowest point of being 55 years old (e.g. in Canada) to approximately being 60+ years old in other countries with the RM experience. Except age and homeownership criteria, the RM approval is not dependable upon the regular credit capacity appraisal likewise the forward mortgage. As there is no regular repayment obligation of the RM borrower, the likelihood of moral hazard behavior is mitigated by requiring from the borrowers to live in the property during the contractual period, in the most of the cases until the death, to pay real-estate taxes and insurance, and finally to take care of their home. In return, the lender will put them a certain amount of money on disposal, in form or regular monthly payment (annuity), credit line, lump sum or some combination of these forms, usually without any restrictions about the purpose of money spending. However, it is assumed that the money should be used for non-speculative purposes, likewise "refinancing a current mortgage loan or paying off other debts, renovation works, health care, home and garden improvements, the payments of debts or going on holiday" (Simón-Moreno, 2019, p. 1016). The aforementioned obligation by the lender ends up when the estimated value of property (after certain borrower's obligations such as fees, earlier debt etc.) is exempted, or in case when borrower violates the loan terms and conditions, sells or permanently moves away from that residence. Nevertheless, the RM contract is the most frequently terminated with the death of borrower or the death of its marriage partner if he or she outlives the borrower. This is usually followed by the lender's take over of a property that was a base for a RM approval and its sale. If there is some surplus between the realized price of the property and the loan proceeds it is distributed among the borrower's heirs. In short, the RM is a type of a loan with "rising debt and falling equity" attributes. The previously described case corresponds to the loan or the mortgage model of the RM, which is widely used in practice. There is also a sales model of the RM, according to which the property is sold to the lender at the beginning, rather than the end of contractual relationship. In both models, the loan amount or received money 
usually reaches up to $50 \%$ of the market value of the property, but is additionally dependable upon the value of the real estate (its condition, location and market movements), payment plan, age of the requestor and costs of the loan (Husáková et al., 2018, pp. 623-625).

Table 1. Reverse mortgage vs. forward mortgage

\begin{tabular}{|c|c|c|}
\hline Feature & Reverse mortgage & Forward mortgage \\
\hline Synonyms & $\begin{array}{l}\text { Home equity conversion } \\
\text { mortgage, old age mortgage, } \\
\text { inverted mortgage, "eating your } \\
\text { home", mortgage for "home rich } \\
\text { and cash poor", lifetime } \\
\text { mortgage }\end{array}$ & Ordinary mortgage \\
\hline $\begin{array}{l}\text { Purpose of } \\
\text { mortgage }\end{array}$ & $\begin{array}{l}\text { To extract money from the home } \\
\text { which someone owns }\end{array}$ & To purchase a home \\
\hline $\begin{array}{l}\text { Prerequisites for } \\
\text { approval }\end{array}$ & $\begin{array}{l}\text { Elderly borrowers with significant } \\
\text { homeownership and valuable } \\
\text { residence; credit capacity and } \\
\text { certain income size are not } \\
\text { obligatory }\end{array}$ & $\begin{array}{l}\text { Sufficient creditworthiness and } \\
\text { income }\end{array}$ \\
\hline $\begin{array}{l}\text { Borrower's } \\
\text { obligations toward } \\
\text { lenders }\end{array}$ & $\begin{array}{l}\text { To live in the property, to } \\
\text { maintain its value and to pay } \\
\text { taxes and insurance; there is no } \\
\text { usual repayment obligation }\end{array}$ & $\begin{array}{l}\text { Repayment obligation until the } \\
\text { end of mortgage loan contract }\end{array}$ \\
\hline Form of payment & $\begin{array}{l}\text { Credit line, lump sum payment, } \\
\text { periodic payments or } \\
\text { combination of payments } \\
\text { received from the lender without } \\
\text { restrictions about the purpose of } \\
\text { money spending }\end{array}$ & Monthly payments \\
\hline $\begin{array}{l}\text { The amount of } \\
\text { debt }\end{array}$ & $\begin{array}{l}\text { Very small at the beginning of } \\
\text { contractual period and very large } \\
\text { at the end of the loan }\end{array}$ & $\begin{array}{l}\text { Very large at the beginning of } \\
\text { contractual period and no debt } \\
\text { remained at the end of the loan }\end{array}$ \\
\hline $\begin{array}{l}\text { Ownership over } \\
\text { the property }\end{array}$ & $\begin{array}{l}\text { Declines during the contractual } \\
\text { period and at the end property } \\
\text { usual becomes an ownership of } \\
\text { a lender }\end{array}$ & $\begin{array}{l}\text { Increases during the contractual } \\
\text { period and at the end property } \\
\text { becomes an ownership of a } \\
\text { borrower }\end{array}$ \\
\hline $\begin{array}{l}\text { Termination of } \\
\text { contract }\end{array}$ & $\begin{array}{l}\text { Death of borrower, violation of } \\
\text { loan contract, permanently } \\
\text { moving away from the property } \\
\text { or selling the property }\end{array}$ & $\begin{array}{l}\text { In case of fulfilling the repayment } \\
\text { obligation or in case of credit } \\
\text { default followed by the takeover } \\
\text { of the property }\end{array}$ \\
\hline Type of mortgage & Rising debt, falling equity & Falling debt, rising equity \\
\hline
\end{tabular}

Source: Authors' presentation based on the listed bibliography.

The relationship between mortgages and homeownership over time is depicted with the figure 1. 


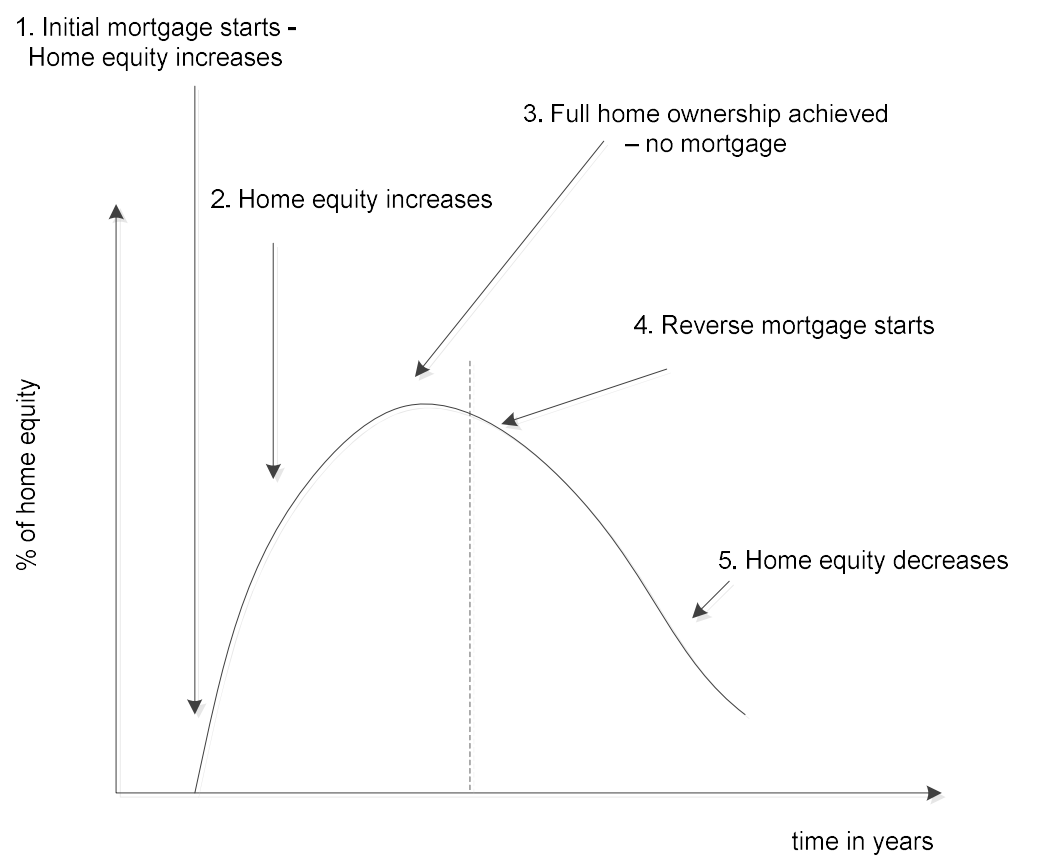

Figure 1. The relationship between mortgages and home equity over time Source: Reed and Gibler (2003), p. 3.

According to a life-cycle hypothesis, using a money trapped in the form of a residential property in an older age via RM would be a rational option, regardless of the size of the regular income. Despite theoretical assumptions, that is not the common case, and the RM remains an alternative source of financing the elders in practice. This might be due to the following barriers and disadvantages of this product:

- Insufficient awareness and/or knowledge about the financial instrument (see e.g. Davidoff et al., 2017),

- Product and approval process complexity (see e.g. Moulton et al., 2017),

- High costs of approval and generally RM expensiveness (see e.g. Moulton et al., 2017)

- Deterioration of the borrower's health and inability to take care for themselves i.e. nursing-home-move risk,

- Losing a homeownership with emotional and inheritance side-effects.

On the other hand, using a RM might increase the quality of borrower's life at their residence and generally their well-being (see e.g. Moulton et al., 2017), without needing to move or sell their homes, what is rather important in case of poor liquidity of the real estate market. It can also give certain freedom to product adopters, as they are able to choose among the various forms of payment. Furthermore, the most of RMs are insured against the drop of the market value what makes their users safe from the potential home loss during their life or from introduction of the repayment obligation. Thus, RM could be used to hedge against house price risk (to lock in home equity) in the period of housing bubble, as "even if property values decline, the RM line of credit retains and grows based on the initial home value" (Moulton et al., 2017, p. 83). Next, borrowing against their home equity 
via RM products might be a way of another intergenerational transfer of wealth and solidarity between RM participants and their heirs, while their children and grandchildren (or other beneficiaries) are younger and spend more money (Chatterjee, 2016, p. 8). Namely, inheriting residential property could be substituted with inheriting some money from the RM approval. Finally, the RM reduces housing costs and can facilitate decision about retirement (Husáková et al., 2018, p. 624).

From a macroeconomic perspective, RM products play an important role in diminishing financial exclusion of elderly people as they extend their access to credit, as well as they downsize the demand for new houses what altogether improves the efficiency of the second-home market (Cosma et al., 2019, p. 1276). Namely, a low-income and poor-health households are expected to benefit the most from RM loans, as well as single (usually female-headed) households, homeowners with modest nonhousing assets, and previous mortgage takers (Nakajima and Telyukova, 2014; Moulton et al., 2017, p. 75). With regards to the argument about the far-reaching favorable impact of the RM, calculations for the e.g. UK predict that every 1 GBP of wealth released through RM generates 2,34 GBP for the wider economy via multiplier effects (Whait et al., 2019). At last, improving the social welfare of senior citizens by RM loans approval should dampen public costs in the social security area, and consequently stimulate personal consumption expenditures throughout enhanced perception of the sustainability of social security systems (Kobayashi et al., 2017, p. 100).

\section{Factors influencing the RM introduction and acceptance}

Supply (introduction) and demand (acceptance) of the RM as an alternative source of financing the elders are driven both by the economic, institutional and political circumstances (contextual variables), but even more important dependable upon the socalled the $\mathrm{X}$ factor or behavioral (sociological, psychological, cultural and emotional) characteristics of the possible RM users. In order to estimate the RM market potential for certain country or area, many scholars focus on the objective opportunities and limitations for the RM introduction, by analyzing the demographic structure of the population, the average pension income, the risk of poverty, the homeownership rate, the real-estate market movements, financial market development etc. (e.g. Haurin and Moulton, 2017; Kobayashi et al., 2017; Tuškan, 2019; Tuškan and Andrašić, 2019). Some authors (e.g. Nakajima and Telyukova, 2014) even foresee that the environment which financial crisis and consequently recession create increases the odds for the RM market development, both in the short and long run. On the other hand, studies that center around the individual's socio-demographic as well as subjective or behavioral factors (risk profile, propensity towards debt, bequest motive behavior etc.) of the interest in RM or its adoption are still scarce, especially for the markets/countries in which there are even legal obstacles for the RM introduction i.e. the nonexistent supply of RM loans. Thus, by focusing mainly on the latter studies, we summarized the references, which might be among the most insightful for explaining the determinants of RM's introduction and acceptance. 
The US were among the first economies in the world (in the 1980s), which enabled not only the necessary legal changes, but also various forms of the public policy support in order to promote the RM usage. Not surprisingly, they have the largest RM market in the world, and are the most fruitful ground for exploring the factors behind the RM adoption. The number of approved RMs in the US recorded an exponential growth up to the year 2009, when it peaked with almost 115.000 of new contracts, after which it continuously declined to a level of about 31.000 of RM loans in 2019 - the lowest point since the year 2003 (Figure 2).

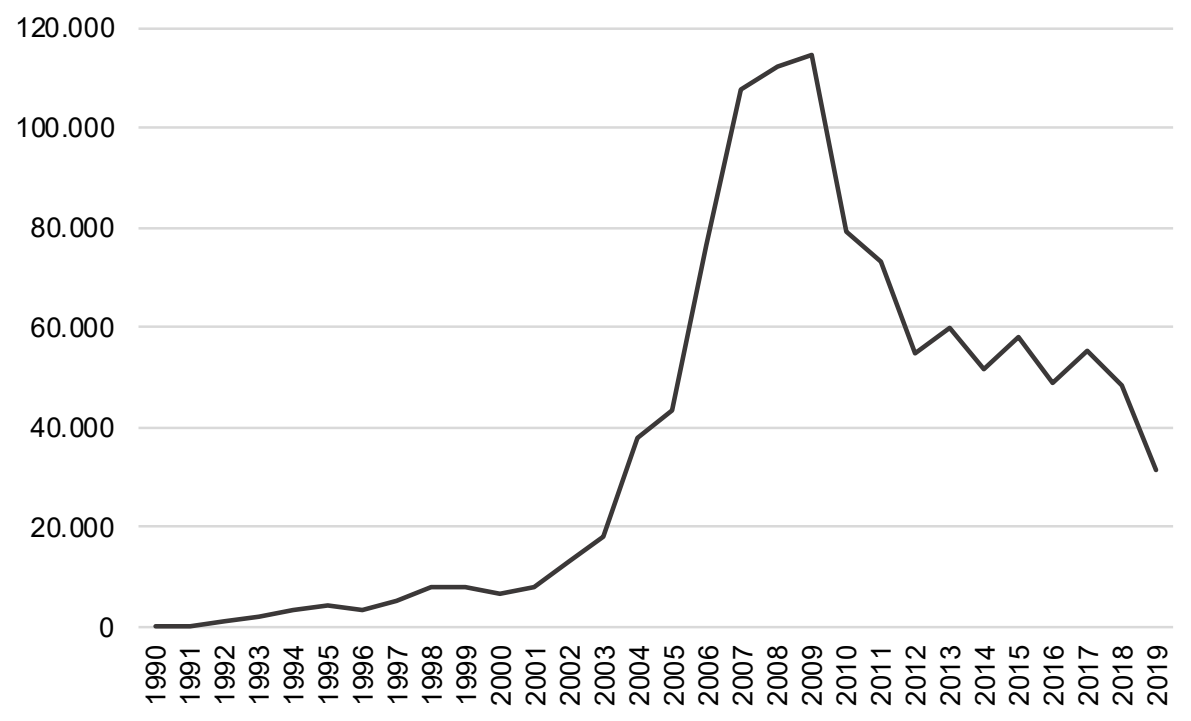

Figure 2. Number of approved RMs in the US

Source: National Reverse Mortgage Lenders Association (NRMLA), official website.

The high interest in the RM product from the 2006-2009 was expected (see Irving and Roughan, 2005) as the "baby boomers" (people born between 1946-1964) began retiring in this period. Namely, the "baby boomer" generation was less saving oriented than their parents did. Thus, the demand for a RM product, which might supplement their spending budget, increased and is projected to grow in future (Moulton et al., 2017, p. 73). RM adopters mostly opted for a lump sum payment (73\% of borrowers in 2011$)$, while the monthly payment was their last option (Reverse Mortgage Alert, website). Furthermore, the common age of RM user has dropped from 74 as of 2003 to 63 in 2009 (Time, website). According to the NRMLA, the average value of the RM market was 16 billions USD in the downturn period (2010-2018). However, the RM market is still recovering from the financial crisis.

Based on approximately 10,600 survey responses, Chatterjee (2016) concluded that the US citizens with a higher net worth of property, modest long-term care insurance coverage as well as those who were more risk averse are more likely to have RM loans. Thus, it seems that many RM adopters use this instrument as a tool to meet their long-term care needs. However, somewhat different conclusions regarding the purpose of signing the RM agreement were found in some other studies. 
For instance, Moulton et al. (2017) analyzed the data set of 1,761 US senior households that sought counseling for a RM between 2006 and 2011 (among which 74\% obtained a RM), and who later on (in the period from 2014-2015) responded to a follow-up survey. They discovered that the most common motivation for considering a RM was to get additional income for everyday expenses (other than health needs) and paying off the forward mortgage debt as well as nonmortgage debt. Among other primary factors influencing the RM decision paying for home improvements, providing financial help to family members, coping with health or disability expenses, postponing other retirement income were recorded. The main causes for not obtaining the RM, besides eligibility criteria, were RM expensiveness, bequest reason, finding another way of managing finances and desire to own home free of any mortgages. The most of RM adopters (4 to 7 years after the RM decision) confirmed that its usage improved the quality of their lives and were satisfied with this financial instrument.

The estimation of the latent demand for RM among the 1,145 Dutch homeowners performed by Dillingh et al. (2017) indicates that around $27 \%$ of respondents aged $45+$ are interested in taking out a RM loan once they retire, while approximately $36 \%$ are indifferent about this matter. The most of the potential RM adopters prefer credit line form of payment $(42 \%)$, rather than lump sum $(10 \%)$ and monthly payments $(15 \%)$, what is in line with the intended usage of the RM loan. Namely, the most frequent spending purposes of the RMs are summarized in the following points: more comfortable living and less worry about money, making some significant expenditures such as home renovation and travelling, and having a last resort in case of insufficient pension income. Among 37\% of respondents to whom the idea of a RM loan is not at all appealing the usual reasons for such attitude are aversion towards banks or debt, bad feeling, the fear of being evicted from the home or optimistic view towards future earnings. Somewhat contrary to expectations, women and those with children or grandchildren, low-income households and those with sufficient savings, as well as poor-health respondents show little interest in this financial innovation. For instance, having (grand)children dampens the demand for RM for about $30 \%$. Finally, the study reveals a low initial familiarity with the RM concept i.e. less than $10 \%$ before the concept clarification during the questionnaire research. Contrary to the perceived financial consumers' benevolence towards the RM adoption in the Netherlands, according to 31 interview of people aged over 65 years, RMs are quite unpopular in Australia, mainly because of the desire to avoid debt and to retain a home for security and precautionary reasons (Whait et al., 2019).

Recently, Cosma et al. (2019) performed an ordered probit regression analysis on the data sample comprised of questionnaire responses of 2,000 Italian households. They found out that younger respondents, respondents residing in Northern Italy and those with presently lower income or expected decrease in the future income show greater interest in the RM products. In addition, respondents with a significant homeownership, those to whom legacy is less important, as well as those who used consumer credits in the last two years were more in favor of adopting the RMs. Finally, survey respondents that have an internal locus of control i.e. perception that they are in control of life events are more oriented towards the RM product. 
Regardless of disparities in the methodological approach and research findings, aforementioned studies have in common developed countries orientation. This is why, we found noteworthy rare projections of the RM adoption in countries of comparable characteristics to Croatia, such as Slovenia, Slovak Republic and Poland.

There is not much prospect that the RM volume in Poland will be remarkable, according to the study by Zbrojewski (2013), who compared motivation of two age groups of questionnaire respondents (the young financial consumers - mostly students aged 18 to 30 , and senior financial consumers over the age of 60 ) to sign a RM agreement. On the basis of 304 respondents in total, only $5,7 \%$ of elderly and $16,8 \%$ of young respondents would adopt a RM instrument, mainly in case of insufficient retirement benefits. Namely, despite the prevailing negative opinions about the current and future pension level, the intergenerational material solidarity and a desire to leave a legacy to family members (around $90 \%$ of respondents in both groups have this intention) is the main reason for the RM aversion. According to a survey results, other obstacles to the RM market development in Poland besides the one of cultural origin seem to the be the lack of potential clients trust in financial institutions and perception of deficient regulatory oversight of the current RM providers. Interestingly, due to marketing campaigns targeted on the senior financial consumers, the latter ones demonstrated higher familiarity with the RM concept (66\% of respondents) in contrast to student population (30\% of respondents).

According to the study for Slovak Republic (Husáková et al., 2018) which encompassed 925 questionnaire respondents aged $65+$, out of the total number of respondents, only $16 \%$ of property owners claimed to be interested in RM loans. About $67 \%$ of those reported problems with paying for regular expenses. Potential adopters of the RM loans would use the money to increase their living standards, for the health care costs coverage, for the reconstruction of their real estate, while some of them would support their loved ones with that money. The rest of respondents are not ready to employ their property in order to overcome financial hardship in old age, due to family solidarity and intergenerational real-estate transfer. Generally, respondents owing a house, and living in a village, were more reluctant towards the RM loans. Slovaks perceive state institutions, rather than private institutions, as the most appropriate for RM service providing.

The research of 930 Slovenian financial consumers that were aged 50 years and over by Sendi et al. (2019) reveals strong rejection of the RM product, as only $1.6 \%$ of the total number of respondents declared that they would accept a loan model of RM. The logistic regression results show that the younger respondents and those with higher level of education were more inclined towards the equity release. The reasons behind such attitudes are found in the place attachment, the perception of a homeownership as a life achievement and strong inheritance considerations.

To sum up, many studies witness that there are inconsistencies in the research findings for different countries about the prototype of RM adopter. This is why, an individual approach to each credit market is requested and in the absence of one for Croatia, this empirical research was conducted. Croatian prudential regulators and other public policymakers as well as bank managers might be interested in these forecasts, especially 
when recent hints about certain large banks considering reverse mortgage introduction are taken into consideration.

\section{Forecasting the RM's market potential for Croatia}

\subsection{Research methodology}

Due to a nonexistent supply of the RM product in the Croatian financial sector, this paper intends to estimate the potential demand for this financial instrument by conducting a research of exploratory nature. Namely, although the matter of the potential size of the Croatian RM's market was already considered inside the EU-focused studies (e.g. Haurin and Moulton, 2017; Tuškan, 2019; Tuškan and Andrašić, 2019), the previous work tackled solely the question of the contextual determinants of the RM introduction, and thus dealt with the secondary data. This empirical research was carried out on a primary data collected through an e-mail survey (as a part of the co-author's research for the diploma thesis) and handled by using the SPSS 23.0. Survey respondents were targeted according to an age criterion in such a manner that respondents belonging to different age groups were equally encompassed by the data sample. Out of 122 questionnaire respondents, 42 were between 18 and 40 years old, 40 respondents were in the age range from 41 to 60 years, while the rest were older than 60. Our questionnaire was composed of 20 questions in total, which tackled the following issues: 1) respondents' experience with the Croatian banks in the area of loans approval, 2) respondents' attitudes towards the Croatian banking sector, 3) respondents' familiarity with the RM product and their willingness to accept it, and 4) general characteristics of respondents. Questions took various forms from single to multiple choice answers, as well as open-ended questions when, for instance "other" category was selected as an answer or in case of a question requiring response about the respondents' unpleasant experience with a bank. Furthermore, respondents who were not familiar with the RM features were asked to read a short text providing some basic clarifications of this product, in order to be able to express their willingness concerning the RM adoption. The work by Koo (2007), Zbrojewski (2013), and Chavez Andersson and Sandström (2013) were helpful in the questionnaire design. Although, the questionnaire is not appended due to a paper size restriction, it is available upon request.

\subsection{Data sample characteristics}

The most of survey respondents were females i.e. out of 122 survey respondents, 75 or $61.5 \%$ were females. Around $42 \%$ of survey respondents were employed (51 respondent), $34 \%$ were retired (41 respondent), with the remaining respondents being either unemployed (16 respondents) or having a full-time student status (14 respondents). Thus, the main sources of income were salary (for 50 respondents), pension income (for 36 respondents), and pocket money, as well as some occasional payments (24 respondents). The homeownership rate was rather high with $63.1 \%$ or 77 survey respondents having some real-estate ownership (either apartment or house). The rest 
were living either at their parents' apartment or house (35 respondents or $28.7 \%$ ) or in rented apartment (9 respondents). The following table provides a more detailed insight into the survey respondents' status and homeownership. Interestingly, among retired population, there are still some respondents without any homeownership.

\section{Table 2. Homeownership and status}

\begin{tabular}{lrrrrr}
\hline & Unemployed & \multicolumn{1}{c}{ Student } & Employed & \multicolumn{1}{c}{ Retired } & \multicolumn{2}{c}{ Total } \\
\hline Own apartment & 2 & 0 & 14 & 17 & 33 \\
Own house & 7 & 1 & 17 & 19 & 44 \\
Parents' apartment & 0 & 6 & 8 & 0 & 14 \\
Parents' house & 6 & 6 & 9 & 0 & 21 \\
Rented apartment & 1 & 1 & 3 & 4 & 9 \\
Other & 0 & 0 & 0 & 1 & 1 \\
\hline Total & 16 & 14 & 51 & 41 & 122 \\
\hline
\end{tabular}

Source: Authors' calculation.

The overall monthly sources of income were only in $25 \%$ of cases higher than the $5.500,00$ Croatian Kuna's (Table 3). Finally, according to a level of formal education, survey respondents with completed secondary school and two-year post-secondary school education dominated the sample as they contributed with almost $55 \%$ of responses $(67$ responses). Survey respondents with university qualifications made $30 \%$ of e-mail responses (37 responses), while those who had the lowest level of formal education or those without any completed formal education were in minority.

Table 3. The overall monthly sources of income (in Croatian Kuna's)

\begin{tabular}{lrrr}
\hline & Frequency & Valid \% & Cumulative $\%$ \\
\hline up to $1.200,00$ & 17 & 14,5 & 14,5 \\
$1.200,01-1.800,00$ & 13 & 11,1 & 25,6 \\
$1.800,01-2.500,00$ & 16 & 13,7 & 39,3 \\
$2.500,01-3.500,00$ & 19 & 16,2 & 55,6 \\
$3.500,01-5.500,00$ & 22 & 18,8 & 74,4 \\
$5.500,01-7.500,00$ & 23 & 19,7 & 94,0 \\
more than $7.500,01$ & 7 & 6,0 & 100,0 \\
\hline Total & 117 & 100,0 & \\
\hline Source: Authors' calculation. & \multicolumn{4}{l}{}
\end{tabular}

\subsection{Research findings}

With a goal of getting an insight into their experience with the Croatian banks in the area of loans approval, respondents were firstly asked to answer whether they already used some type of a bank loan. Out of 122 survey respondents, 70 respondents answered that they have never used any type of a bank loan. Among those 52 respondents to whom the loans were granted, current account loan (36 responses) and consumer loans (23 responses) were the most frequent ones. In order to inform themselves about the bank loans the most of respondents tend to contact employees of bank branches (36 responses) and talk to their family and friends (24 responses). Other usual sources of information 
about the bank loans likewise bank's official websites or any type of advertisements are poorly exploited. The most of the bank loan non-users (70 survey respondents) declared that they were not in need to apply for the loan (40 responses). Nevertheless, negative attitudes toward going into debt (14 responses) or distrust in Croatian banks (14 responses) are among other reasons for the bank loan avoidance. With regards to the matter of trust in the domestic banking sector, out of 122 survey respondents, only 28 trust Croatian banks, while almost $77 \%$ of respondents either do not trust Croatian banks (52 respondents or $42.6 \%$ ) or do not have a clear opinion about that (42 responses or $34.4 \%$ ). Contrary to those results, only 17 respondents had some unpleasant experience with Croatian banks, such as unprofessional approach to a client, insufficient knowledge about some product/case and overcharge. To sum up, although the majority of survey respondents endeavor to avoid getting a loan from the bank, those who use short or medium term loans likewise current account or consumer loans, might be candidates for the RM as they obviously do not have sufficient income to maintain certain living standard.

Furthermore, we asked our survey respondents to point out their familiarity with the RM product. Approximately $24 \%$ of them (29 respondents) claimed that they are familiar with the RM notion, while the rest were either not familiar with the term at all $(67 \%$ or 82 respondents) or were not sure about it (9\% or 11 respondents) (Figure 3).

Among those respondents that were familiar with the RM notion, younger respondents dominate (Table 4), as well as those who were employed and had higher educational level. Namely, according to the Kruskal-Wallis test results, there is a significant difference in respondents' age and familiarity with the RM term (Chi-quare=29,978; sig.=0,000). Table 5 discloses the ranks. In addition, the Chi-square test confirms the relevance of the "status" variable for the RM familiarity (Table 6), whereby the Pearson's contingency coefficient is 0,440 with empirical significance $\alpha^{*}=0,000$. According to another Kruskal-Wallis test results (revealed in table 7), respondents with a higher level of formal education showed higher awareness of the RM notion (Chi-square=11,751; sig. $=0,003$ ). Among other potentially interesting variables, respondent's gender was not significant in explaining the disparities in RM familiarity, while some others (e.g. main source of income and homeownership) were statistically significant but are considered to be closely related or even derived from the respondent's status, so we omitted them from results presentation.

Table 4. Age and familiarity with the RM product

\begin{tabular}{|c|c|c|c|c|}
\hline \multirow{2}{*}{ Age } & \multicolumn{3}{|c|}{ Familiarity with the RM product } & \multirow{2}{*}{ Total } \\
\hline & Not familiar & Not sure & Familiar & \\
\hline $18-40$ & 16 & 7 & 19 & 42 \\
\hline $41-60$ & 28 & 4 & 8 & 40 \\
\hline more than 60 & 38 & 0 & 2 & 40 \\
\hline Total & 82 & 11 & 29 & 122 \\
\hline
\end{tabular}

Source: Authors' calculation. 


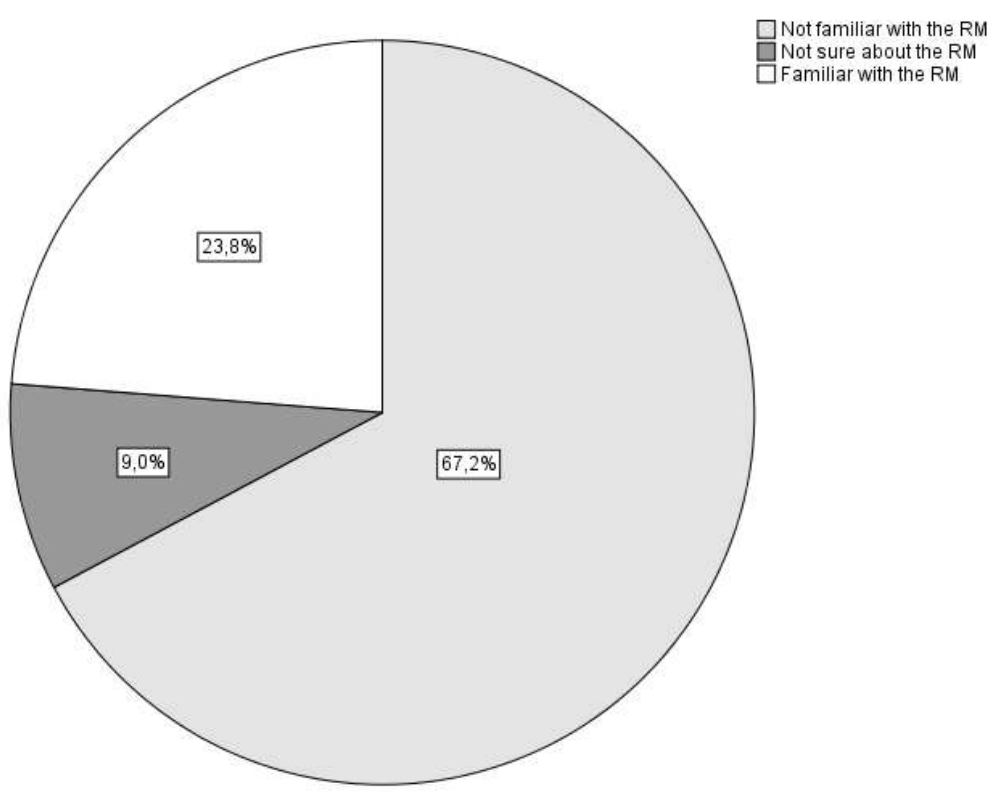

Figure 3. Familiarity with the RM product

Source: Authors' calculation.

Table 5. Kruskal-Wallis test - ranks for age and RM familiarity

\begin{tabular}{llrr}
\hline & Familiarity with the RM & N & Mean Rank \\
product & 82 & 73,04 \\
\hline Age & Not familiar & 11 & 36,41 \\
& Not sure & 29 & 38,40 \\
& Familiar & 122 & \\
Total & \multicolumn{2}{c}{} \\
\hline
\end{tabular}

Source: Authors' calculation.

Table 6. Chi-square test for status and familiarity with the RM product

\begin{tabular}{lrrr} 
& Value & df & $\begin{array}{c}\text { Asymptotic } \\
\text { Significance } \\
\text { (2-sided) }\end{array}$ \\
\hline Pearson Chi-Square & $29,334^{\mathrm{a}}$ & 6 & 0,000 \\
Likelihood Ratio & 31,846 & 6 & 0,000 \\
Linear-by-Linear Association & 3,823 & 1 & 0,051 \\
\hline $\mathrm{N}$ of Valid Cases & 122 & & \\
\hline a. 6 cells (50,0\%) have expected count less than 5. The minimum \\
expected count is 1,26. \\
$\quad$ Source: Authors' calculation.
\end{tabular}


Table 7. Kruskal-Wallis test - ranks for level of formal education and RM familiarity

\begin{tabular}{llrr}
\hline & Familiarity with the RM & N & \multirow{2}{*}{ Mean Rank } \\
& product & 82 & 54,72 \\
\hline Level of formal & Not familiar & 11 & 70,91 \\
education & Not sure & 29 & 77,10 \\
& Familiar & 122 & \\
& Total & & \\
\hline
\end{tabular}

Source: Authors' calculation.

After a brief explanation of the most common features of the RM product, the respondents were asked to express their attitude toward the potential RM adoption. More than $66 \%$ of respondents (81 respondent) were reluctant about the RM acceptance (Figure 4). Approximately $23 \%$ of survey respondents would adopt RM product only if certain conditions would be met. For instance, 20 respondents claim to accept RM if they would not have heirs, or in case their children would have their own property (8 respondents). Thus, only $11 \%$ would use the RM possibility either because of the insufficient monthly income or due to an opportunity to convert their tangible assets into liquidity. Altogether, a conclusion is made about the lack of demand for the RM in Croatia, mainly due to a bequest motive. Thus, the most of respondents are not even interested in getting any further information about the RM (almost 60\%), while the rest of them would be interested in receiving additional information possibly (24\%) or certainly (around $16 \%$ ).

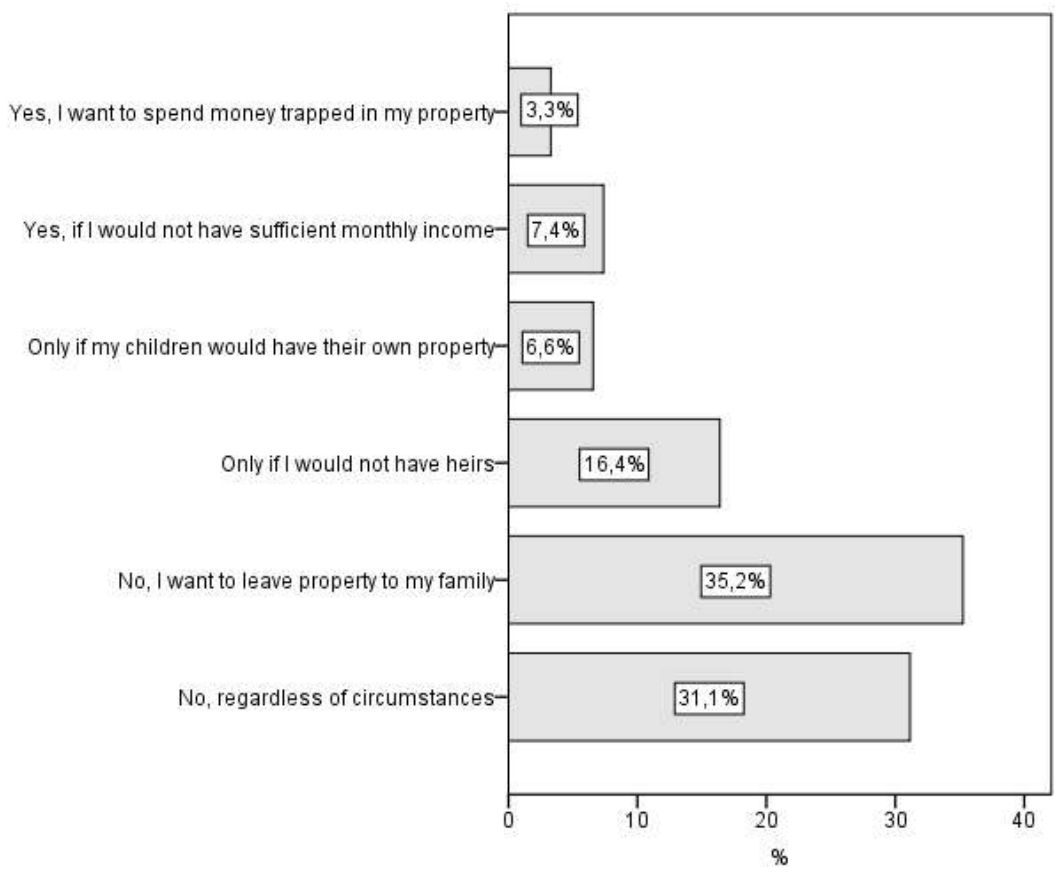

Figure 4. Potential RM acceptance

Source: Authors' calculation. 
Interestingly, among those who would consider the adoption of the RM product was a great number of respondents that were initially not aware of the RM financial instrument (Table 8). However, a brief explanation of RM sounded good enough to get some interest in using this product. On the other hand, those who were initially familiar with the RM term (mostly younger respondents) would accept that service the least. Although, the Chi-square test for the aforementioned relation was not statistically significant, KruskalWallis test confirmed (Chi-square $=22,257$; sig. $=0,000$ ) that the older respondents were both more determined to adopt the RM service, as well as to refuse to use it (Table 9).

Furthermore, no significant disparities between females and males were obtained regarding the RM acceptance. However, when the "status" variable was tested, we noticed that the employed and retired respondents showed the highest willingness for the RM adoption, contrary to students and unemployed (Chi-square=25,456; sig.=0,044). Except the main source of income, which is derived from the status, other variables were not significantly related to the RM acceptance.

Concerning their attitude toward ending up in nursing home for the elderly (Figure 5 ), the most of survey respondents disagreed with that option (37 responses), or were ready to accept it solely in case of their inability to take care of themselves (57 responses). The rest of respondents would perhaps consider that scenario (18 responses) or fully agrees with it (10 responses).

Table 8. Familiarity with the RM product and RM acceptance

\begin{tabular}{lcccr}
\hline \multirow{2}{*}{$\begin{array}{l}\text { Reverse mortgage acceptance } \\
\text { Not familiar }\end{array}$} & Not sure & Familiar & \multirow{2}{*}{ Total } \\
\hline $\begin{array}{l}\text { No, regardless of } \\
\text { circumstances }\end{array}$ & 28 & 2 & 8 & 38 \\
$\begin{array}{l}\text { No, I want to leave property } \\
\text { to my family }\end{array}$ & 25 & 3 & 15 & 43 \\
$\begin{array}{l}\text { Only if I would not have heirs } \\
\text { Only if my children would }\end{array}$ & 13 & 4 & 3 & 20 \\
$\begin{array}{l}\text { have their own property } \\
\text { Yes, if I would not have }\end{array}$ & 5 & 2 & 1 & 8 \\
$\begin{array}{l}\text { sufficient monthly income } \\
\text { Yes, I want to spend money }\end{array}$ & 9 & 0 & 0 & 9 \\
trapped in my property & 2 & 0 & 2 & 4 \\
\hline Total & 82 & 11 & 29 & 122 \\
\hline \multicolumn{1}{c}{ Source: Authors' calculation. } & & & &
\end{tabular}

Table 9. Kruskal-Wallis test - ranks for age and RM acceptance

\begin{tabular}{llrr}
\hline & $\begin{array}{l}\text { Reverse mortgage } \\
\text { acceptance }\end{array}$ & N & Mean Rank \\
\hline Age & $\begin{array}{l}\text { No, regardless of } \\
\text { circumstances }\end{array}$ & 38 & 74,95 \\
& $\begin{array}{l}\text { No, I want to leave property } \\
\text { to my family }\end{array}$ & 43 & 58,36 \\
Only if I would not have heirs & 20 & 35,85 \\
\hline
\end{tabular}




\begin{tabular}{lcc}
$\begin{array}{l}\text { Only if my children would } \\
\text { have their own property } \\
\text { Yes, if I would not have }\end{array}$ & 8 & 52,25 \\
$\begin{array}{l}\text { sufficient monthly income } \\
\text { Yes, I want to spend money } \\
\text { trapped in my property }\end{array}$ & 9 & 80,17 \\
\hline Total & 4 & 72,25 \\
\hline
\end{tabular}

Source: Authors' calculation.

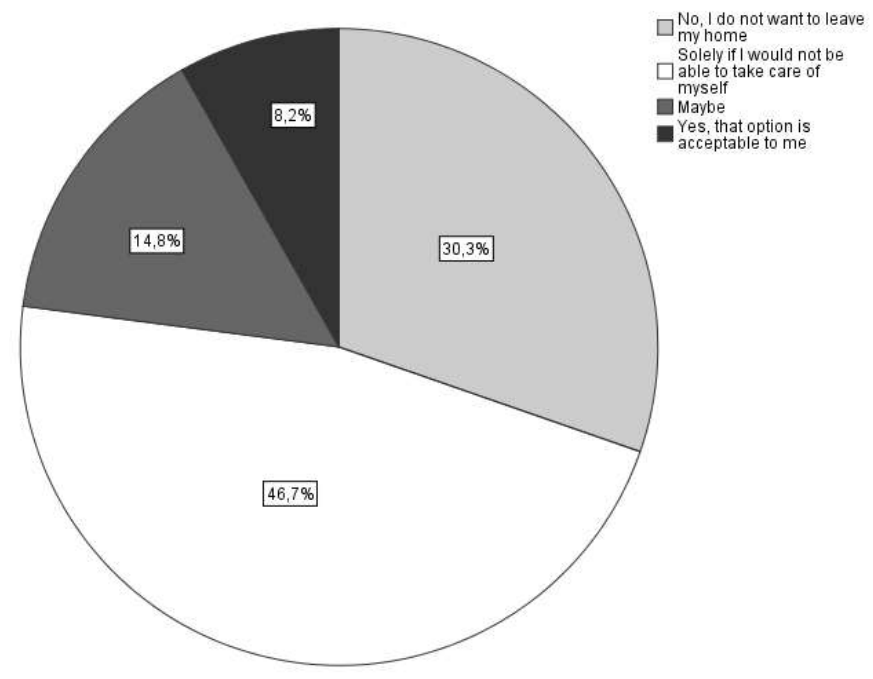

Figure 5. Attitude about ending up in nursing home

Source: Authors' calculation.

Table 10. RM acceptance and attitude about ending up in nursing home

\begin{tabular}{|c|c|c|c|c|c|}
\hline \multirow[b]{2}{*}{ Reverse mortgage acceptance } & \multicolumn{4}{|c|}{ Attitude about ending up in nursing home } & \multirow[b]{2}{*}{ Total } \\
\hline & $\begin{array}{c}\text { No, I do not } \\
\text { want to leave } \\
\text { my home }\end{array}$ & $\begin{array}{l}\text { Solely if I would } \\
\text { not be able to } \\
\text { take care of } \\
\text { myself }\end{array}$ & Maybe & $\begin{array}{c}\text { Yes, that } \\
\text { option is } \\
\text { acceptable to } \\
\text { me }\end{array}$ & \\
\hline $\begin{array}{l}\text { No, regardless of } \\
\text { circumstances }\end{array}$ & 20 & 14 & 3 & 1 & 38 \\
\hline $\begin{array}{l}\text { No, I want to leave property to } \\
\text { my family }\end{array}$ & 12 & 21 & 8 & 2 & 43 \\
\hline Only if I would not have heirs & 2 & 11 & 5 & 2 & 20 \\
\hline $\begin{array}{l}\text { Only if my children would have } \\
\text { their own property }\end{array}$ & 2 & 5 & 0 & 1 & 8 \\
\hline $\begin{array}{l}\text { Yes, if I would not have } \\
\text { sufficient monthly income }\end{array}$ & 1 & 6 & 2 & 0 & 9 \\
\hline $\begin{array}{l}\text { Yes, I want to spend money } \\
\text { trapped in my property }\end{array}$ & 0 & 0 & 0 & 4 & 4 \\
\hline Total & 37 & 57 & 18 & 10 & 122 \\
\hline
\end{tabular}


To sum up, Croatian citizens that were encompassed with this survey are almost equally reluctant to ending up in a nursing home or adopting the reverse mortgage (Table 10). Thus, a conclusion can be made that they expect from their family members to take care of them in an older age (in every way) or that they are just rather optimistic regarding their financial and personal capabilities.

\section{Conclusion}

In the present study, we examine the connection between certain sociodemographic variables such as age, gender, education level, status, source of income, homeownership and familiarity with the RM product, as well as propensity to use it. With reference to the behavioral aspects, we investigate the omnipresent "bequest syndrome" as well as aversion towards ending up in a nursing home for elders i.e. emotional bond to the home as possible reasons behind the (dis)interest in the RM. Finally, the lack of trust in the domestic banking sector, a negative look on getting into debt as well as avoidance of borrowing of any type of bank loans put emphasis on some credit market attributes, which in our case additionally downsize a demand for this financial service. Altogether, the estimations of the latent demand for RM do not encourage introduction of this financial innovation in Croatia, despite every contextual, to be more precise, economic justification for its implementation.

Firstly, there is a certain aversion towards the bank debt, as well as distrust in the Croatian banking sector among the respondents. However, the omnipresent use of the current account loan and expensive consumer debt indicates insufficient income level of households, what could positively affect the RM acceptance. Secondly, the familiarity with the RM notion was around quarter and significantly higher among younger and more educated respondents as well as those who were employed. Nevertheless, awareness of the RM product does not explain the interest in its take up, as those who were initially not aware of the RM notion were more determined to adopt the product. Thirdly, around $23 \%$ of the total number of respondents would conditionally accept the RM loan, and only $11 \%$ would do that due to financial and opportunistic reasons. Once again, the willingness to leave property to inheritors is confirmed at the main behavioral obstacle of the RM's introduction and acceptance. On the other hand, low-income, materialism, excessive consumption and different lifestyle of new generations, as well as the practice of inheriting some real-estate from their parents, rather than earning them or acquiring them through forward mortgages, could easily change this attitude, especially when negative projections about pensions and prospects for some new economic crises appearance are taken into consideration. Thus, a further research concerning this topic is welcomed, especially if a larger data set and more sophisticated statistical approach are planned.

Acknowledgment: The present study has been presented at the $12^{\text {th }}$ International Conference "Economies of the Balkan and Eastern European Countries", EBEEC 2020, that has been online in Opatija, Croatia from May $29^{\text {th }}$ to $31^{\text {th }} 2020$ (http://ebeec.ihu.gr/). 


\section{References}

Chatterjee, S., (2016), Reverse Mortgage Participation in the United States: Evidence from a National Study, International Journal of Financial Studies, Vol. 4(1), No. 5, pp. 1-10.

Chavez Andersson, K., Sandström, J., (2013), Investigating a Psychological Perspective of Reverse Mortgage - How is Reverse Mortgage Perceived by Potential Borrowers in Sweden?, Umeå School of Business and Economics, Master Thesis.

Cosma, S., Cosma, S., Peluso, A. M., (2019), Determinants of Older Consumers' Interest in Home Equity Conversion Products, International Journal of Bank Marketing, Vol. 37, No. 5, pp. 1275-1295.

Davidoff, T., Gerhard, P., Post, T., (2017), Reverse Mortgages: What Homeowners (Don't) Know and How it Matters, Journal of Economic Behavior and Organization, Vol. 133, pp. 151-171.

Dillingh, R., Prast, H., Rossi, M., Urzì Brancati, C., (2017), Who Wants to Have Their Home and Eat it Too? Interest in Reverse Mortgages in the Netherlands, Journal of Housing Economics, Vol. 38, December, pp. 25-37.

Eurostat, EUROPOP2018.

Eurostat, (2019), Ageing Europe - looking at the lives of older people in the EU.

Haurin, D., Moulton, S., (2017), International Perspectives on Homeownership and Home Equity Extraction by Senior Households, Journal of European Real Estate Research, Vol. 10, No. 3, pp. 245-276.

Husáková, M., Rievajová, E., Sika, P., Šipikalová, S., (2018), The Reverse Mortgage as a Financial Tool for Increasing the Living Standards of Seniors in the Slovak Republic, Ekonomický časopis, Vol. 66, No. 6, pp. 621-640.

Irving, B., Roughan, T., (2005), The Development of the Reverse Mortgage Market, The Capco Institute Journal of Financial Transformation, pp. 1-9.

Kobayashi, M., Konishi, S., Takeishi, T., (2017), The Reverse Mortgage Market in Japan and Its Challenges, Cityscape: A Journal of Policy Development and Research, Vol. 19, No. 1, pp. 99-118.

Koo, I. (2007), Empirical Analysis on the Second Generation's Perception of Parents' Application for Reverse Mortgage in Korea, KDI School of Public Policy and Management, Master Thesis.

Moulton, S., Loibl, C., Haurin, D., (2017), Reverse Mortgage Motivations and Outcomes: Insights From Survey Data, Cityscape: A Journal of Policy Development and Research, Vol. 19, No. 1, pp. 73-97.

Nakajima, M., Telyukova, I. A., (2014), Reverse Mortgage Loans: A Quantitative Analysis, Federal Reserve Bank of Philadelphia, Working paper No. 14-27, September.

National Reverse Mortgage Lenders Association (NRMLA), official website.

Reed, R., Gibler, K. M., (2003), The Case for Reverse Mortgages in Australia - Applying the USA Experience, 9th Annual Pacific Rim Real Estate Society Conference. Brisbane, Australia.

Reverse Mortgage Alert, website.

Sendi, R., Filipovič Hrast, M., Kerbler, B., (2019), Asset-Based Welfare: Is Housing Equity Release a Viable Option for Pensioners in Slovenia, Journal of European Social Policy, Vol. 29, No. 4 , pp. 577-589.

Simón-Moreno, H., (2019), The Regulation of Reverse Mortgages as a Source of Income in Retirement: Policy Options and Legal Drivers, Journal of Housing and the Built Environment, Vol. 34, pp. 1005-1022.

Time, website.

Tuškan, B., (2019), Analysis of Demographic and Socio-Economic Trends Significant for the European Reverse Mortgage Industry Development Potential, Proceedings of the 8th 
International Scientific Symposium: Economy of Eastern Croatia - Vision and Growth, Osijek, Croatia, pp. 534-549.

Tuškan, B., Andrašić, A., (2019), Analiza i zastupljenost primjene modela otpuštanja kapitala iz vrijednosti nekretnina među starijom populacijom u Europskoj uniji, Zbornik Ekonomskog fakulteta u Zagrebu, Vol. 17, No. 2, pp. 1-17.

Whait, R. B., Lowies, B., Rossini, P., McGreal, S., Dimovski, B., (2019), The Reverse Mortgage Conundrum: Perspectives of Older Households in Australia, Habitat International, Vol. 94, 102073, December.

Zbrojewski, P., (2013), Prospects for the Development of Equity Release Products in Poland Reverse Mortgage from a Cultural Perspective, Real Estate Management and Valuation, Vol. 21, No. 2, pp. 5-12. 